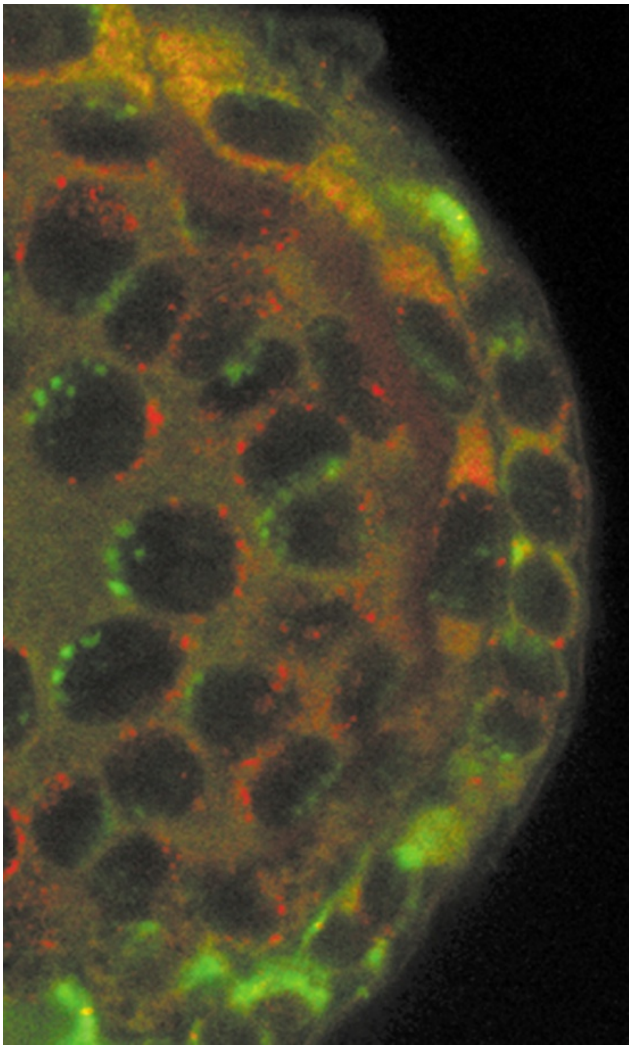

— remains to be worked out, as does identification of the responsible gene or genes within the $\mathrm{PH} 1$ locus. However, it is clear that $\mathrm{PH} 1$ is more divorce lawyer than matchmaker, breaking up unsuitable pairings so perfect couples can meet.

Christopher Surridge Senior Editor, Nature

(2) References and links ORIGINAL RESEARCH PAPER Martinez-Perez, E., Shaw, P. \& Moore, G. The PH1 locus is needed to ensure specific somatic and meiotic centromere association. Nature 411, 204-207 (2001) WEB SITE Moore laboratory

transport depends on the GTPase cycle of Ran. So, is there a similar mechanism for the dissociation of Pex 5 cargo in the peroxisomal matrix? On the other hand, peroxisomal import resembles the $\Delta \mathrm{pH}$ pathway of chloroplast thylakoids, in that a fully folded protein (which a receptor would necessarily be) can cross the membrane of an otherwise tightly sealed compartment. Whatever the new mechanism, the paradigm's lost. Raluca Gagescu

D) References and links ORIGINAL RESEARCH PAPER Dammai, V. \& Subramani, S. The human peroxisomal targeting signal receptor, Pex $5 p$, is translocated into the peroxisomal matrix and recycled to the cytosol. Cell 105, 187-196 (2001)

FURTHER READING Titorenko, V. I. \& Rachubinski, R. A. The life cycle of the peroxisome. Nature Rev. Mol. Cell Biol. 2 357-368 (2001)

H I G H L I G H S

DEVELOPMENT

\section{Destiny takes a hand}

The unexpected turns that life can take are often appealing, but for cells, their fates must be tightly controlled. To ensure this, the same mechanism is used time and again to distinguish between two cell types - transcriptional regulation, leading to differential gene expression. A less common mechanism is now highlighted by Okabe and colleagues in Nature, who show that, for one neuronal cell type, this decision is made at the next step - translational repression.

Okabe and colleagues focused on a Drosophila neural precursor that divides asymmetrically to produce one neuronal and one non-neuronal cell type. The key determinant, Tramtrack69 (Ttk69), is necessary and sufficient to specify non-neuronal identity, and Notch signalling is known to act upstream of Ttk69. But how does it achieve this?

The authors found that ttk69 mRNA levels are similar in both cells, leading them to propose that its activity is regulated post-transcriptionally. From genetic analysis, a good candidate for regulating ttk69 mRNA is Musashi (Msi), which encodes an RNA-binding protein. To test this possibility, the authors identified Msi's target sequences and confirmed their presence in the $3^{\prime}$ untranslated region (3'UTR) of $t$ tk69 mRNA. Using a gel mobility-shift assay, they then showed that Msi binds to these sequences.

To address the significance of this binding, they used a translational reporter system in $\mathrm{S} 2$ cells. And they found that Msi inhibits translation of ttk69 mRNA by binding to the $3^{\prime} \mathrm{UTR}$.

One curiosity is that both cells have Msi. So how does the neuronal cell escape repression of Ttk69? The authors predict that Notch signalling blocks Msi activity. In the cell where Notch signalling is blocked, then, Msi is free to repress translation of Ttk69. Alison Schuldt

(2) References and links ORIGINAL RESEARCh PAPER Okabe, $\mathrm{M}$. et al. Translational repression determines a neuronal potential in Drosophila asymmetric cell division. potential in Drosophila asy
Nature 411, 94-98 (2001)
IN BRIEF

\section{DEVELOPMENT}

Xenopus Sprouty2 inhibits FGF-mediated gastrulation movements but does not affect mesoderm induction and patterning.

Nutt, S. L. et al. Genes Dev. 15, 1152-1166 (2001)

Fibroblast growth factor (FGF)-mediated signalling is required for specifying the vertebrate body plan. Sprouty acts as an antagonist of FGF signalling. But whereas Drosophila melanogaster Sprouty inhibits the Ras/mitogen-activated protein kinase (MAPK) pathway, the newly cloned Xenopus laevis sprouty2 gene product, Xspry2, inhibits calcium mobilization. This paper provides evidence for the existence of at least two FGFdependent pathways involved in Xenopus mesoderm patterning and morphogenesis.

\section{CANCER}

A novel role for the Bcl-2 protein family: specific suppression of the RAD51 recombination pathway.

Saintigny, Y. et al. EMBO J. 20, 2596-2607 (2001)

Bcl-2, famous for its anti-apoptotic activity, now has a new role as a genetic mutator. It does this by inhibiting the Rad51dependent conservative recombination pathway, probably by affecting post-translational modification of the Rad51 protein. As this occurs independently of the ability of Bcl-2 to repress apoptosis through its association with Bax, these new results now indicate that $\mathrm{Bcl}-2$ can confer a cancer-prone phenotype by two separate means.

\section{OXIDATIVE STRESS}

Role of ATM in oxidative stress-mediated c-Jun phosphorylation in response to ionizing radiation and $\mathrm{CdCl}_{2}$.

Lee, S. A. et al. J. Biol. Chem. 276, 11783-11790 (2001)

The ataxia telangiectasia gene product is required for oxidative stress-induced G1 and G2 checkpoint function in human fibroblasts.

Shackelford, R. E. et al. J. Biol Chem. 17 April (2001) (epub ahead of print)

Elevated Cu/Zn-SOD exacerbates radiation sensitivity and hematopoietic abnormalitities of Atm-deficient mice.

Peter, Y. et al. EMBO J. 20, 1538-1546 (2001)

Some of the phenotypes observed in ataxia telangiectasia (AT) patients - sensitivity to ionizing radiation and cancer predisposition - are thought to result from a failure of cells to respond to oxidative damage. Three groups now provide a molecular basis for this, showing that the gene mutated in AT, $A T M$, responds to oxidative damage by triggering G1 and G2 cellcycle checkpoints, the induction of $\mathrm{p} 53$ and the activation of cJun by phosphorylation. Accordingly, elevated levels of $\mathrm{Cu} / \mathrm{Zn}$ superoxide dismutase exacerbate radiation sensitivity in ATMdeficient mice. 